\begin{tabular}{l|l} 
Potaice & e-ISSN: 2655-9404 p-ISSN: 2721-8376 \\
Vol. 5 No. 1, Februari 2022 & DOI: 10.20473/ntr.v5i1.33658 \\
\hline
\end{tabular}

Article history: Submitted 14 February 2022; Accepted 18 February 2022; Available online 24 February 2022.

\title{
Tanggung Gugat Penerima Pinjaman Aplikasi Pinjaman Online atas Penyalahgunaan Data Pribadi Milik Pihak Ketiga
}

\author{
Indira Retno Aryatie, Farah Diba, Karina Ardelia Irnanda \\ indira@fh.unair.ac.id \\ Universitas Airlangga
}

\begin{abstract}
Online loan agreements can be done easily and quickly and without complicated terms. One of the conditions in applying for an online loan is granting contact list access by the debtor to the provider as emergency access to collect his receivables to the debtor. However, the provision of the contact number is done by the debtor without the consent of the third party of the contact owner. This is a misuse of personal data in the form of third party's contact numbers. This research aims to analyze the misuse of personal data in the form of third party's contact numbers by debtors and what legal efforts can be made by the third party concerned. The approach used in this research consists of a statutory approach and a conceptual approach. The result of this study is that the misuse of personal data in the form of third party's numbers carried out by debtors is an unlawful act, thus the legal efforts that can be done by the aggrieved third party is filing a claim for damages on the basis of unlawful acts to the Court.

Keywords: Online Loans; Personal Data; Unlawful Acts; Legal effort.
\end{abstract}

\begin{abstract}
Abstrak
Perjanjian pinjam-meminjam uang secara onlinedapat dilakukan dengan mudah dan cepat serta tanpa persyaratan yang rumit. Salah satu syarat dalam melakukan pengajuan pinjaman online tersebut yaitu pemberian akses daftar kontak oleh penerima pinjaman kepada penyelenggara sebagai akses darurat untuk menagih piutangnya kepada penerima pinjaman. Namun pemberian nomor kontak tersebut dilakukan penerima pinjaman tanpa persetujuan pihak ketiga pemilik kontak. Hal tersebut merupakan penyalahgunaan data pribadi berupa nomor kontak pihak ketiga. Penelitian ini bertujuan untuk menganalisis perbuatan penyalahgunaan data pribadi berupa nomor kontak pihak ketiga oleh penerima pinjaman dan upaya hukum apa yang dapat dilakukan oleh pihak ketiga yang bersangkutan. Pendekatan yang digunakan dalam penelitian ini terdiri dari pendekatan perundang-undangan dan pendekatan konseptual. Hasil dari penelitian ini adalah penyalahgunaan data pribadi berupa nomor pihak ketiga yang dilakukan oleh penerima pinjaman merupakan perbuatan melanggar hukum, maka upaya hukum yang dapat dilakukan oleh pihak ketiga yang dirugikan adalah pengajuan gugatan ganti rugi atas dasar perbuatan melanggar hukum kepada Pengadilan.

Kata Kunci: Pinjaman Online; Data Pribadi; Perbuatan Melanggar Hukum; Upaya Hukum.

Copyright () 2022 Indira Retno Aryatie, Farah Diba, Karina Ardelia Irnanda. Published in Notaire. Published by Universitas Airlangga, Magister Kenotariatan.
\end{abstract}

\section{Pendahuluan}

Saat ini akses terhadap informasi semakin mudah, begitu pula untuk kebutuhan lainnya, semua dapat diakses melalui gawai. Berbagai aplikasi menyajikan layanan yang memadai, hampir segala macam kebutuhan dapat 
terpenuhi hanya dengan mengakses internet atau mengunduh aplikasi yang menyediakan berbagai macam fasilitas dalam genggaman. Kemajuan teknologi tentu menjadi hal yang sangat menguntungkan bagi masyarakat, karena memberikan berbagai macam kemudahan dalam mendapatkan berbagai hal yang dibutuhkan. Salah satunya adalah kebutuhan akan uang, masyarakat dapat mengakses layanan jasa keuangan melalui gawai yang dimiliki tanpa harus hadir ke lembaga keuangan terkait. Kemudahan ini memang sangat menguntungkan, tetapi masih ada pihak-pihak yang memanfaatkan kemajuan teknologi ini untuk tujuan yang merugikan masyarakat.

Dalam hal seseorang ingin mengajukan kredit, banyak fasilitas layanan jasa keuangan yang dapat diakses melalui gawai yang tersambung dengan internet, namun ketatnya persyaratan dan ketentuan dalam pengajuan kredit pada pihak lembaga keuangan baik bank maupun non-bank membuat banyak orang memilih alternatif lain, yaitu mengajukan kredit melalui aplikasi pinjaman online. Hal ini dilakukan karena mereka membutuhkan uang dalam waktu yang cepat tanpa harus melewati persyaratan yang rumit dan ketat. Dalam hal mengajukan kredit pada aplikasi tersebut, calon penerima pinjaman akan dimintai persetujuan agar penyelenggara melalui aplikasi tersebut dapat mengakses data-data yang ada pada gawai yang dimiliki oleh calon penerima pinjaman, di antaranya berupa daftar kontak, media, dan lain sebagainya. Hal ini dilakukan dengan tujuan apabila penerima pinjaman tidak dapat melunasi utangnya tepat waktu, maka penyelenggara pinjaman online tersebut akan menghubungi nomor-nomor yang terdapat dalam daftar kontak di gawai penerima pinjaman agar penerima pinjaman dapat melunasi utangnya. Nomor-nomor yang terdapat dalam daftar kontak tersebut oleh penyelenggara dianggap sebagai penjamin apabila penerima pinjaman wanprestasi meskipun tidak terdapat perjanjian penjaminan oleh pihak ketiga pemilik nomor kontak tersebut. Dalam hal ini nomor - nomor tersebut bukan sebagai penjamin yang terikat dalam perjanjian tersebut, tetapi hanya sebagai pihak yang dapat dihubungi jika penerima pinjaman melakukan wanprestasi. Berdasarkan Pasal 7 Peraturan Otoritas Jasa Keuangan Nomor 77 
/POJK.01/2016 tentang Layanan Pinjam Meminjam Uang Berbasis Teknologi Informasi (Selanjutnya disebut POJK No.77/2016), penyelenggara pinjaman online, wajib mengajukan pendaftaran dan perizinan kepada Otoritas Jasa Keuangan (OJK). Tidak semua penyelenggara pinjaman online memiliki izin dari OJK untuk menjalankan usahanya. Hanya bermodalkan gawai dan ktp, calon penerima pinjaman dapat mengajukan kredit melalui pinjaman online dengan mudah dan cepat meskipun persetujuan pemberian akses daftar kontak dilakukan oleh penerima pinjaman, dalam daftar kontak tersebut terdapat data-data milik orang lain yang diberikan penerima pinjaman kepada penyelenggara pinjaman online. Sebagai contoh, berikut daftar nama-nama penyelenggara pinjaman online yang terdaftar dan berizin dari OJK per Januari 2022 yang meminta persetujuan akses kontak gawai:

1. KoinWorks:Pinjaman Usaha, P2P;

2. Ringan;

3. UKU;

4. KIMO;

5. TOKO MODAL;

6. ETHIS;

7. Modalku;

8. Singa;

9. KlikA2C;

10. danabijak.

Dalam hal ini penyelenggara pinjaman online tersebut mengakses daftar kontak penerima pinjaman guna menagih pinjaman penerima pinjaman melalui pihak ketiga yang terdaftar dalam kontak penerima pinjaman. Upaya tersebut pada dasarnya merupakan akses darurat yang digunakan penyelenggara pinjaman online dalam menagih pinjaman ke penerima pinjaman, namun ternyata hal tersebut merugikan pihak ketiga yang ada dalam daftar kontak penerima pinjaman tersebut karena nomornya dapat diakses oleh pihak lain tanpa persetujuannya serta dipergunakan bukan untuk kepentingannya. Dalam hal ini kerugian yang dialami oleh pihak ketiga tersebut yaitu tersebarnya nomor pihak ketiga, tersebarnya data pribadi secara akurat, gangguan ketenangan pihak ketiga, jeleknya moral dalam masyarakat yang seakan - akan diikutsertakan dengan perjanjian yang jelas- jelas 
tidak terikat dengan dirinya. Berdasarkan latar belakang tersebut maka ditarik suatu rumusan masalah sebagai berikut:

1. Perbuatan Melanggar Hukum atas Penyalahgunaan Data Pihak Ketiga oleh Penerima Pinjaman Pinjaman Online

2. Upaya hukum atas Penyalahgunaan Data Milik Pihak Ketiga oleh Penerima Pinjaman Pinjaman Online

\section{Metode Penelitian}

Metode penelitian yang digunakan dalam penelitian ini menggunakan metode penelitian normatif yaitu penelitian yang memberikan penjelasan sistematis antara aturan-aturan yang mengatur mengenai pinjaman online, data pribadi elektronik, perbuatan melanggar hukum, tanggung gugat, dan ganti rugi. Kemudian setelah dilakukan analisis hubungan antara peraturan, menjelaskan daerah kesulitan dan mungkin memprediksi pembangunan masa depan. ${ }^{1}$ Dalam hal ini akan diakukan analisis antar peraturan terkait tanggung gugat penerima pinjaman atas penyalahgunaan data pribadi pihak ketiga yaitu dalam Peraturan Otoritas Jasa Keuangan Nomor 77/POJK.01/2016 tentang Layanan Pinjam Meminjam Uang Berbasis Teknologi Informasi ,Undang - Undang Nomor 19 Tahun 2016 tentang Perubahan Atas Undang-Undang Nomor 11 Tahun 2008 Tentang Informasi Dan Transaksi Elektronik dan peraturan perundang undangan terkait, menganalisis penyalahgunaan dan kerugian yang dialami pihak ketiga dan memberikan preskripsi terkait penyalahgunaan data pribadi pihak ketiga oleh penerima pinjaman di masa yang akan datang. Pendekatan yang digunakan adalah pendekatan perundang-undangan (statute approach) dan pendekatan konseptual (conceptual approach). Pendekatan konseptual dilakukan manakala peneliti tidak beranjak dari aturan hukum yang ada. Selain itu juga digunakan pendekatan perundang-undangan yang dilakukan dengan menelaah peraturan perundang-undangan yang berkaitan dengan tanggung gugat pemilik

${ }^{1}$ Peter Mahmud Marzuki, Penelitian Hukum: Edisi Revisi (Prenada Media 2017).[32]. 
data pribadi dan perbuatan melanggar hukum terkait penyalahgunaan penggunaan data pribadi pihak ketiga yang tidak berkepentingan dalam pinjaman online oleh penerima pinjaman.

\section{Perbuatan Melanggar Hukum atas Penyalahgunaan Data Pribadi Pihak Ketiga oleh Penerima Pinjaman Pinjaman Online}

Perikatan merupakan suatu hubungan hukum antara dua pihak yang melahirkan hak dan kewajiban pada masing-masing pihak yang berupa prestasi. ${ }^{2}$ Salah satu pihak berhak atas prestasi dan juga dibebani atas suatu prestasi terhadap pihak lainnya. Berdasarkan Pasal 1233 Burgerlijk Wetboek (selanjutnya disingkat menjadi BW), lahirnya perikatan didasarkan pada dua hal,yaitu perikatan yang lahir dari perjanjian dan perikatan yang lahir dari undang-undang. Perikatan yang bersumber dari perjanjian dibuat oleh para pihak berdasarkan kesepakatan para pihak, sedangkan perikatan yang lahir dari undang-undang dibuat atas dasar kehendak yang berkaitan dengan perbuatan manusia yang terdiri dari dua pihak. ${ }^{3}$ Dalam hal perjanjian pinjam - meminjam uang berbasis teknologi informasi, penyelenggara pinjaman online dan penerima pinjaman saling mengikatkan diri dengan satu sama lain yang melahirkan suatu akibat hukum yaitu lahirnya hak dan kewajiban yang merupakan kesepakatan dari perjanjian yang telah disepakati. Dalam perjanjian pinjam-meminjam tersebut berdasarkan ketentuan pada Pasal 20 POJK No.77/2016 diatur bahwa perjanjian pemberian pinjaman antara penerima pinjaman dan pemberi pinjaman online dituangkan dalam Dokumen Elektronik yang paling sedikit memuat:
a. nomor perjanjian;
b. tanggal perjanjian;
c. identitas para pihak;
d. ketentuan mengenai hak dan kewajiban para pihak;
e. jumlah pinjaman;
f. suku bunga pinjaman;
g. nilai angsuran;
h. jangka waktu;

\footnotetext{
${ }^{2}$ Subekti, Pokok-Pokok Hukum Perdata (Intermasa 2003).[81].

${ }^{3}$ Suharnoko, Hukum Perjanjian (Prenada Media 2004).[117].
} 
i. objek jaminan (jika ada);

j. rincian biaya terkait;

k. ketentuan mengenai denda (jika ada); dan

1. mekanisme penye lesaian sengketa.

Dokumen elektronik tersebut (selanjutnya disebut perjanjian) diberikan oleh penyelenggara pinjaman online kepada penerima pinjaman guna melakukan perjanjian pinjam - meminjam uang. Perjanjian tersebut tetaplah sah dengan dipenuhinya unsur-unsur sebagaimana diatur dalam Pasal 1320 BW, yaitu sepakat, cakap, adanya suatu objek tertentu dan kausa yang diperbolehkan. Syarat pertama yaitu sepakat yang terjadi dalam perjanjian pinjam-meminjam uang tersebut yaitu penerima pinjaman melakukan pengajuan pinjaman dengan nilai yang telah disepakati oleh penerima pinjaman dan penyelenggara pinjaman online, kemudian setelah disepakati dengan melakukan perjanjian elektronik dan semua syarat terpenuhi oleh penerima pinjaman maka terjadinya suatu perjanjian. Dalam perjanjian pinjam - meminjam uang tersebut penerima pinjaman tidak memiliki kewajiban memberikan jaminan kepada penyelenggara pinjaman online akan tetapi jika dalam hal ini penerima pinjaman gagal bayar atau wanprestasi maka penyelenggara pinjaman online akan menghubungi daftar kontak yang ada dalam penerima pinjaman. Upaya tersebut pada dasarnya merupakan akses darurat yang digunakan penyelenggara pinjaman online guna menagih piutangnya kepada penerima pinjaman. Syarat kedua adalah cakap, kecakapan para pihak untuk melakukan perjanjian berkaitan dengan wewenang dan/atau usia para pihak dalam melakukan perbuatan hukum yang akan dilakukan. Dalam perjanjian pinjam - meminjam tersebut tentunya dalam melakukan pinjaman penerima pinjaman tersebut wajib cakap hukum. Cakap hukum disini yaitu telah berumur 18 Tahun. Penyelenggara pinjaman online disini akan meminta identitas penerima pinjaman untuk melihat kecapakan penerima pinjaman seperti Kartu Tanda Penduduk (KTP) atau Surat Tanda Mengemudi (SIM) atau Kartu Keluarga (KK) yang nantinya akan dicheck oleh penyelenggara pinjaman online apakah penerima pinjaman tersebut telah cakap hukum atau tidak. Hal tersebut dilakukan untuk menilai apakah penerima pinjaman dapat melakukan perbuatan 
hukum. Kesepakatan dan kecakapan merupakan syarat subjektif karena berkaitan dengan subjek yang membuat perjanjian yang apabila tidak terpenuhi maka akan berakibat dapat dibatalkannya perjanjian tersebut. ${ }^{4}$ Syarat ketiga adalah suatu objek tertentu dalam perjanjian tersebut. Objek dari perjanjian pinjam-meminjam disini adalah uang. Dimana penerima pinjaman dan penyelenggara pinjaman online melakukan perjanjian pinjam - meminjam dengan obyek uang, Selain itu, syarat yang lainnya adalah kausa yang diperbolehkan, yaitu perjanjian tersebut dibuat dengan tujuan untuk dilaksanakan dengan disertai itikad baik serta tidak bertentangan dengan peraturan perundang-undangan, ketertiban umum, dan kesusilaan sebagaimana diatur dalam Pasal 1337 BW. ${ }^{5}$ Penerima pinjaman dan penyelenggara pinjaman online wajib bertikad baik dan dalam perjanjian pinjam - meminjamnya yang dituangkan dalam dokumen elektronik tidak melanggar ketentuan dalam peraturan peraturan perundang - undangan, ketertiban umum dan kesusilaan. Dengan terpenuhinya syarat-syarat tersebut di atas maka perjanjian tersebut sah dan lahirlah perikatan antara kedua belah pihak. Dalam perjanjian pinjam-meminjam yang terjadi antara penyelenggara pinjaman online dan penerima pinjaman melalui aplikasi, telah dipenuhi syarat-syarat sahnya perjanjian tersebut. Perjanjian pinjam-meminjam melahirkan perikatan antara penerima pinjaman dan penyelenggara pinjaman online, sedangkan pihak ketiga yang data pribadinya ikut menjadi bagian dari perjanjian yang terjadi antara penerima pinjaman dan penyelenggara pinjaman online tidak memiliki hubungan hukum baik dengan pihak penyelenggara pinjaman online maupun penerima pinjaman. Nomor kontak pihak ketiga diberikan oleh pihak ketiga kepada penerima pinjaman baik sebelum maupun pada saat perjanjian pinjam-meminjam dibuat oleh penerima pinjaman. Dalam hal ini penerima pinjaman memiliki akses terhadap data pihak ketiga berupa nomor kontak, namun pemberian akses tersebut tidak serta merta dianggap bahwa data yang telah diserahkan kepada

\footnotetext{
${ }^{4}$ Agus Yudha Hernoko, Hukum Perjanjian: Asas Proporsionalitas Dalam Kontrak Komersial (Prenadamedia Group 2014).[160].

5 ibid.[194-196].
} 
penerima pinjaman merupakan milik penerima pinjaman. Dalam hal ini seakan - akan penerima pinjaman mendapat persetujuan akses nomor pihak ketiga guna kepentingan penerima pinjaman.

Dalam persetujuan pemberian akses daftar kontak yang dimiliki oleh penerima pinjaman terdapat data pribadi milik pihak ketiga. Berdasarkan pengertian dalam Pasal 1 angka 29 Peraturan Pemerintah Nomor 71 Tahun 2019 tentang Penyelenggaraan Sistem dan Transaksi Elektronik (selanjutnya disebut dengan PP 71/2019), yang dimaksud dengan data pribadi adalah "setiap data tentang seseorang baik yang telah teridentifikasi dan/atau dapat diidentifikasi secara mandiri atau digabungkan dengan informasi lainnya baik dengan cara langsung maupun secara tidak langsung melalui Sistem Elektronik dan/atau nonelektronik". Sedangkan berdasarkan Pasal 1 angka 22 Undang-Undang Nomor 24 Tahun 2013 tentang Administrasi Kependudukan (selanjutnya disebut dengan UU Administrasi Kependudukan), yang dimaksud dengan data pribadi adalah "data perseorangan tertentu yang disimpan, dilindungi, dan dikendalikan kebenaran serta dilindungi kerahasiaannya". Sebagaimana telah dijelaskan di atas bahwa pihak ketiga tidak memiliki hubungan hukum dengan penerima pinjaman maupun penyelenggara pinjaman online, maka apabila terjadi penyalahgunaan atas data pribadinya yang telah dengan suka rela diberikan kepada penerima pinjaman sebelumnya, hal tersebut bukan merupakan wanprestasi. Belum ada kategori yang jelas mengenai kedudukan nomor kontak sebagai data pribadi, oleh karena itu terdapat berbagai polemik mengenai hak apa yang dilanggar apabila terjadi penyalahgunaan data pribadi. Nomor kontak seseorang merupakan data pribadi karena menyangkut data orang yang bersangkutan. Sebagai data pribadi maka nomor kontak harus disimpan dan dilindungi kerahasiannya kecuali orang yang bersangkutan menyebarluaskan nomornya tersebut sehingga siapapun dapat mengetahui nomornya. Berdasarkan Pasal 2 ayat (3) Peraturan Menteri Komunikasi dan Informasi Nomor 20 Tahun 2016 tentang Perlindungan Data Pribadi Dalam Sistem Elektronik data pribadi sebagai privasi merupakan kebebasan Pemilik Data Pribadi untuk menyatakan rahasia atau tidak menyatakan rahasia data pribadinya, kecuali ditentukan lain sesuai dengan ketentuan peraturan perundang-undangan. 
Berdasarkan ketentuan dalam Pasal 26 ayat (1) Undang-Undang Nomor 19 Tahun 2019 tentang Perubahan atas Undang-Undang Nomor 11 Tahun 2008 tentang Informasi dan Transaksi Elektronik (selanjutnya disebut sebagai UU ITE) penggunaan maupun pemberian akses atas suatu data pribadi yang meliputi informasi seseorang harus dilakukan dengan persetujuan pemilik data pribadi bersangkutan. Penjelasan Pasal tersebut menyebutkan bahwa perlindungan dari data pribadi merupakan hak pribadi (privacy rights) yang terdiri atas hal-hal sebagai berikut:

a. Hak untuk menikmati kehidupan pribadi dan bebas dari segala macam gangguan;

b. Hak untuk dapat berkomunikasi bersama orang lain tanpa adanya tindakan mengawas-ngawasi;

c. Hak untuk dapat mengawasi akses informasi terkait kehidupan pribadi dan data seseorang.

Dalam hal seseorang menyalahgunakan data pribadi seseorang, yaitu menggunakan data pribadi tersebut tanpa persetujuan pemiliknya, maka dengan demikian orang tersebut telah melanggar hak pribadi orang tersebut. Pihak ketiga dalam memberikan nomor kontaknya kepada orang lain, dalam hal ini penerima pinjaman, telah memberikan persetujuannya agar penerima pinjaman dapat menggunakan nomornya untuk kepentingan komunikasi secara pribadi. Namun meskipun nomor pihak ketiga telah diperoleh dengan itikad baik oleh penerima pinjaman, dalam hal ini penerima pinjaman tidak serta merta mendapatkan persetujuan untuk dapat memberikan akses nomor pihak ketiga tersebut kepada orang lain yaitu penyelenggara pinjaman online dalam perjanjian pinjam-meminjam uang tesebut. Persetujuan penggunaan informasi atas data pribadi sebagaimana dimaksud dalam Pasal 26UU ITE adalah untuk penggunaan tertentu yang disetujui oleh pemilik data bersangkutan dan tidak boleh bertentangan dengan tujuan awal atau hal yang terkait dengan tujuan awal penggunaan data tersebut yang telah disetujui oleh pemilik data pribadi yang bersangkutan. ${ }^{6}$ Pemberian nomor kontak

\footnotetext{
${ }^{6}$ Sinta Dewi Rosadi, 'Prinsip-Prinsip Perlindungan Data Pribadi Nasabah Kartu Kredit Menurut Ketentuan Nasional Dan Implementasinya' (2017) 19 Sosiohumaniora.[209].
} 
pribadi kepada orang lain secara sukarela seringkali dianggap sebagai persetujuan berbuat bebas terhadap nomor tersebut yang merupakan data pribadi milik yang bersangkutan sehingga rentan terjadi penyalahgunaan. Dalam hal pemberian nomor kontak oleh pihak ketiga kepada penyelenggara pinjaman online sekalipun tidak dilakukan dengan suatu perjanjian tertulis, tujuan pemberian nomor kontak tersebut adalah untuk menjalin komunikasi secara pribadi yang hanya dapat diakses oleh penerima pinjaman dan bukan untuk diberikan kepada orang lain kecuali nomor tersebut disebarluaskan sendiri oleh yang bersangkutan. Dengan demikian, persetujuan yang diberikan oleh pihak ketiga sebagai pemilik nomor kontak hanya sebatas untuk memberikan akses kepada penerima pinjaman untuk dapat menghubunginya secara pribadi. Apabila penerima pinjaman menggunakan nomor kontak tersebut untuk diberikan kepada orang lain, dalam hal ini termasuk penyelenggara pinjaman online, dimana hal tersebut tidak sesuai dengan tujuan awal pemberian nomor kontak oleh pihak ketiga, maka perbuatan penggunaan nomor kontak selain untuk menjalin komunikasi secara pribadi dapat diartikan sebagai hal yang bertentangan dengan persetujuan tujuan awal penggunaan data pribadi dari pemilik data tersebut, sehingga dapat diartikan tidak ada persetujuan dari pihak ketiga atas pemberian akses nomor kontak kepada penyelenggara pinjaman online. Dengan demikian, penerima pinjaman yang telah memberikan akses kepada penyelenggara pinjaman online untuk melihat daftar kontak yang mencakup nomor kontak pihak ketiga tanpa persetujuan pemilik datanya telah melakukan penyalahgunaan terhadap data pribadi berupa nomor kontak tersebut. Dengan kata lain penerima pinjaman menjadikan nomor pihak ketiga sebagai akses darurat untuk menagih utang kepada penerima pinjaman jika penerima pinjaman gagal bayar kepada penyelenggara pinjaman dalam perjanjian pinjam - meminjam uang tersebut. Penyalahgunaan data pribadi tersebut merupakan perbuatan melanggar hukum. Pada UU ITE tersebut telah ada pengaturan mengenai transaksi elektronik termasuk perdagangan melalui internet, namun seringkali tidak dapat mengakomodir kasus perbuatan melanggarhukum dalam transaksi elektronik tersebut, dikarenakan luasnya cakupan pengertian perbuatan 
melanggarhukum yang tidak diatur secara eksplisit atau secara khusus dalam UU ITE tersebut sehinggaperaturan terkait perbuatan melanggarhukum dapat merujuk pada ketentuan Pasal 1365 BW. ${ }^{7}$

Hoge Raad merumuskan pandangan luas mengenai perbuatan melanggar hukum. Pada rumusannya, Hoge Raad mempergunakan rumusan yang terdapat dalam rancangan Heemskerk yang mana yang dimaksud perbuatan melanggar hukum tidak sama dengan melanggar undang-undang tetapi perbuatan melanggar hukum harus diartikan sebagai "berbuat" atau "tidak berbuat" yang melanggar hak oranglain atau bertentangan dengan kewajiban hukum si pembuat atau bertentangan dengan asas kesusilaan dan kepatuhan dalam masyarakat, baik terhadap diri atau benda orang lain. Rumusan itu dijabarkan dalam "Standart Arrest" 31 Januari 119 dalam perkara kasus Cohen dan Lindenbaum. Penafsiran tersebut tidak beralasan karena melanggar hukum tidak sama dengan melanggar undang-undang. Menurut Hoge Raad perbuatan melanggar hukum harus didefinisikan dengan "berbuat" atau "tidak berbuat" yang mengambil hak orang lain atau tidak sesuai dengan kewajiban hukum si pelaku atau kesusilaan atau kepatuhan di dalam masyarakat, baik terhadap diri pelaku tersebut atau benda milik orang lain". Sejak tahun 1919, Hoge Raad mulai menafsirkan Perbuatan Melanggar Hukum dalam arti luas pada perkara Lindenbaum v. Cohen dengan mengatakan Perbuatan Melanggar Hukum harus diartikan sebagai berbuat atau tidakberbuat yang bertentangan dengan: ${ }^{8}$

a. Hak subjektif orang lain;

b. Kewajiban hukum pelaku;

c. Kaedah kesusilaan; atau

d. Kepatutan dalam masyarakat.

Pasal 1365 BW mengatur bahwa, "Tiap perbuatan melanggar hukum, yang memberikan kerugian kepada orang lain, mewajibkan seorang karena

${ }^{7}$ Hetty Hassanah, 'Analisis Hukum Tentang Perbuatan Melawan Hukum Dalam Transaksi Bisnis Secara Online (E-Commerce) Berdasarkan Burgerlijke Wetboek Dan Undang-Undang Nomor 11 Tahun 2008 Tentang Informasi Dan Transaksi Elektronik' (2016) 32 Jurnal Wawasan Yuridika.[40].

8 Sugali, 'Gugatan Perdata Perbuatan Melawan Hukum' (Sugali E Rekan, 20 May 2020) $<$ https://sugalilawyer.com/gugatan-perdata-perbuatan-melawan-hukum/> accessed 13 February 2022. 
kesalahannyamemberikan kerugian itu dan mengganti kerugian tersebut." Perbuatan melanggar hukum merupakan perbuatan seseorang yang bertentangan dengan hak orang lain, yaitu hak subjektif orang lain yang diatur oleh undang-undang. ${ }^{9}$ Hal ini berarti tidak semua hak yang dilanggar dapat disebut sebagai perbuatan melanggar hukum, melainkan hanya hak-hak tertentu saja yang diatur dalam undang-undang. Sebagaimana dijelaskan sebelumnya bahwa perlindungan data pribadi merupakan hak pribadi, maka apabila penerima pinjaman tidak mengindahkan hal ini dan meyalahgunakan data pribadi pihak ketiga dengan cara memberikan akses nomor kontak pihak ketiga tanpa persetujuannya kepada penyelenggara pinjaman online, maka ia telah melanggar hak subjektif pihak ketiga tersebut, dalam hal ini hak pribadinya.

\section{Upaya hukum atas Penyalahgunaan Data Pribadi Milik Pihak Ketiga Terhadap Penerima Pinjaman Pinjaman Online}

Penyalahgunaan data pribadi atas daftar kontak milik pihak ketiga oleh penerima pinjaman yang diberikan kepada penyelenggara pinjaman online pada dasarnya merupakan Perbuatan Melanggar Hukum sebagaimana diatur dalam Pasal 1365 BW. Dimana pihak ketiga tersebut yang memiliki nomor dirugikan atas penyalahgunaan data pribadi berupa nomor pribadi tersebut. Seseorang yang dianggap telah melakukan perbuatan melanggar hukum dapat dikenakan sanksi dengan mengganti kerugian yang diderita korban akibat kesalahannya itu, melalui gugatan yang diajukan kepada lembaga peradilan ataupun lembaga penyelesaian sengketa di luar pengadilan. Berdasarkan hal tersebut, maka pihak ketiga pemiliki nomor tersebut dapat mengajukan gugatan ganti rugi. Berdasarkan ketentuan Pasal 26 (2) UU ITE menyatakan "Setiap Orang yang dilanggar haknya sebagaimana dimaksud pada ayat (1) dapat mengajukan gugatan atas kerugian yang ditimbulkan berdasarkan Undang-Undang ini". Penerima pinjaman tersebut telah menggunakan

9 Prihati Yuniarlin, 'Penerapan Unsur-Unsur Perbuatan Melawan Hukum Terhadap Penyelenggara Pinjaman Online Yang Tidak Mendaftarkan Jaminan Fiducia’ (2012) 19 Jurnal Media Hukum.[7]. 
data pribadi berupa nomor pribadi pihak ketiga tanpa persetujuan pihak ketiga yang bersangkutan dan hal ini merupakan perbuatan yang melanggar ketentuan dalam Pasal 26 ayat (1) UU ITE. Gugatan ganti rugi tersebut dapat diajukan dengan dalih adanya perbuatan melanggar hukum yang dilakukan penerima pinjaman dan penyelenggara pinjaman online, namun demikian harus dapat dibuktikan dan dipertanggungjawabkan kebenaran adanya perbuatan melanggar hukum dimaksud melalui pembuktian unsur - unsur dari perbuatan melanggar hukum ini sebagaimana diatur dalam Pasal 1365 BW, yang terdiri dari:

\section{a. Adanya suatu perbuatan melanggar hukum}

Suatu perbuatan melanggar hukum selalu dimulai oleh perbuatan dari pelakunya. ${ }^{10}$ Perbuatan yang dimaksud di sini adalah bahwa si pelaku berbuat sesuatu (dalam arti aktif) maupun tidak berbuat sesuatu (dalam arti pasif). ${ }^{11}$ Umumnya diterima anggapan bahwa dengan perbuatan di sini dimaksudkan, baik berbuat sesuatu (dalam arti aktif) maupun tidak berbuat sesuatu (dalam arti pasif), misalnya tidak berbuat sesuatu, padahal seseorang tersebutmemilikikewajiban hukum dalam membuatnya, kewajiban akan lahir dari hukum yang berlaku (dikarenakan terdapat juga kewajiban yang lahir dari suatu kontrak). Dengan demikian maka, terhadap perbuatan melanggar hukum, maka tidak ada unsur "persetujuan atau kata sepakat" dan juga tidak ada unsur "kausa yang diperbolehkan" sebagaimana yang terdapat dalam kontrak. ${ }^{12}$

Dalam kaitannya dengan perbuatan dalam penyalahgunaan data pribadi berupa nomor pribadi pihak ketiga tersebut, tindakan penerima pinjaman dan penyelenggara pinjaman online tersebut dikategorikan sebagai perbuatan melanggar hukum dalam arti "berbuat" dimana penyelenggara pinjaman online dan penerima pinjaman melakukan perjanjian pinjam meminjam uang secara online melalui dokumen elektronik, perbuatan tersebut disepakati penyelenggara

\footnotetext{
${ }^{10}$ Ferdiansyah Putra and Ghansham Anand, 'Perlindungan Hukum Terhadap Para Pihak Yang Dirugikan Atas Penyuluhan Hukum Oleh Notaris' (2018) 8 Hukum dan Masyarakat Madani. [113].

${ }^{11}$ Yuniarlin, Op.cit.[6]

12 Indah Sari, 'Perbuatan Melawan Hukum (PMH) Dalam Hukum Pidana Dan Hukum Perdata' (2020) 11 Jurnal Ilmiah Hukum Dirgantara.[67].
} 
pinjaman online dan penerima pinjaman, akan tetapi penerima pinjaman tanpa persetujuan pihak ketiga memberikan daftar nomor pribadi pihak ketiga kepada penyelenggara pinjaman online . Data pribadi berupa nomor pihak ketiga tersebut digunakan sebagai akses daruratjika penerima pinjaman tidak membayar utangnya kepada penyelenggara pinjaman online, sehingga penyelenggara pinjaman online dapat mengakses daftar kontak penerima pinjaman yang merupakan nomor pihak ketiga serta dapat menghubungi nomor pihak ketiga dan menagihnya jika penerima pinjaman gagal bayar. Dengan demikian maka penerima pinjaman tersebut telah melakukan penyalahgunaan terhadap data pribadi berupa nomor pihak ketiga tersebut. Perbuatan tersebut melanggar hak subjektif berupa nomor pihak ketiga dimana hak subjektif tersebut merupakan hak mutlak pihak ketiga yang hanya bisa dikuasi pihak ketiga dalam melakukan sesuatu atau bertindak, selain itu keditur dalam perjanjian pinjam meminjam uang tersebut telah lalai dimana ia tanpa mempertimbangkan dan menanyakan dahulu kepada penerima pinjaman a pakah pihak ketiga yang diakses nomor pribadinya oleh penyelenggara pinjaman online telah mendapat persetujuan dari pihak ketiga selaku pemilik nomor tersebut. Dengan demikian, maka penerima pinjaman tersebut dianggap telah menyalahgunakan data pribadi berupa nomor pribadi pihak ketiga dan penyelenggara pinjaman online juga telah melakukan penyalahgunaan data prbadi berupa nomor pihak ketiga dikarenakan ia tidak menanyakan dulu kepada penerima pinjaman apakah pihak ketiga setuju atau tidak datanya diakses. Dimana data nomor pribadi tersebut digunakan penyelenggara pinjaman online sebagai akses darurat untuk menagih utang penerima pinjaman jika penerima pinjaman gagal bayar. Selain itu perbuatan tersebut telah melanggar kesusilaan dan kepatutan dalam masyarakat yang berakibat merugikan pihak ketiga selaku pemilik nomor dan berisiko terjadi kebocoran data pribadi pihak ketiga.

\section{b. Adanya kesalahan}

Pasal 1365 BW mensyaratkan adanya unsur "kesalahan" dalam suatu perbuatan melanggar hukum, maka perlu diketahui bagaimanakah cakupan dari unsur keselahan tersebut. Suatu tindakan dianggap oleh hukum mengandung 
unsur kesalahan sehingga dapat dimintakan tanggung jawabnya secara hukum jika memenuhi unsur-unsur sebagai berikut: ${ }^{13}$

1. Ada unsur kesengajaan;

2. Ada unsur kelalaian;

3. Tidak ada alasan pembenar atau alasan pemaaf, seperti keadaan overmacht, membela diri, tidak waras, dan lain-lain.

Bila dilihat dari model pengaturan dalam BW tentang perbuatan melanggar hukum lainnya, dan seperti juga di negara-negara dalam sistem hukum Eropa Kontinental, maka model tanggung jawab hukum di Indonesia adalah tanggung jawab dengan unsur kesalahan (kesengajaan dan kelalaian), seperti terdapat dalam Pasal 1365 BW. Dalam kaitannya dengan penyalahgunaan data pribadi berupa nomor pihak ketiga oleh penerima pinjaman tersebut jelas bahwa penyalahgunaan tersebut dilakukan dengan unsur kesengajaan. Dimana penerima pinjaman tersebut sengaja menggunakan data pribadi berupa nomor pihak ketiga tanpa persetujuannya, sehingga perbuatan tersebut dikategorikan sebagai perbuatan dengan unsur kesengajaan. Selain itu penyelenggara pinjaman online yang mengakses nomor pihak ketiga tersebut tanpa menanyakan terlebih dahulu kepada penerima pinjaman apakah pemilik nomor tersebut setuju atau tidak digunakan nomornya untuk akses darurat penerima pinjaman gagal bayar juga merupakan unsur kesengajaan. Perbuatan kesengajaan tersebut merupakan penyimpangan atas penyalahgunaan nomor pihak ketiga yang berakibat terdapat kerugian kepada pihak ketiga dan berisiko terjadi kebocoran data pribadi pihak ketiga.

\section{c. Adanya kerugian}

Pasal 1365 BW menyebutkan adanya kewaijban bagi pembuat kerugian untuk mengganti kerugian tersebut. Ganti kerugian yang dimaksud berupa kerugian materiil dan immateriil, biasanya kerugian tersebut diberikan dalam bentuk uang atau barang, namun ganti kerugian ini bisa pula diberikan dalam hal pemulihan

${ }^{13}$ Rizqy Rizqy and Syahrizal Syahrizal, 'Tinjauan Yuridis Terhadap Perbuatan Melawan Hukum Dan Sanksi Nya' (2019) 3 Jurnal Justisia : Jurnal Ilmu Hukum, Perundang-undangan dan Pranata Sosial.[243]. 
keadaan sesuatu, jika ganti kerugian ini tidak dapat dilakukan, maka bisa dituntut uang paksa/dwangsom walaupun uang paksa ini bukan termasuk dalam hal ganti kerugian akan tetapi hanya sebagai peneguhan supaya ganti kerugian yang dimaksud diterapkan dan dilaksanakan. Kerugian dalam perbuatan melanggar hukum terdapat dua macam, yaitu kerugian berupa harta kekayaan yang berupa kerugian atas kerugian yang diderita dan keuntungan yang diharapkan dan kerugian moril yang berupa kerugian akibat ketakutan, keterkejutan, sakit, dan kehilangan kesenangan hidup. ${ }^{14}$

Perbuatan melanggar hukum sebagaimana diatur dalam Pasal 1365 BW ini dapat pula digunakan sebagai dasar untuk mengajukan ganti kerugian atas perbuatan yang dianggap melanggar hukum. ${ }^{15}$ Perlu diketahui bahwa pengertian kerugian materiil yaitu kerugian yang nyata-nyata ada yang diderita oleh seseorang, sedangkan kerugian immateriil adalah kerugian atas manfaat yang kemungkinan akan diterima oleh pemohon di kemudian hari atau kerugian dari kehilangan keuntungan yang mungkin diterima oleh seseorang di kemudian hari. Dalam gugatan perbuatan melanggar hukum tidak ada pengaturan yang jelas mengenai ganti kerugian tersebut namun sebagaimana diatur dalam Pasal 1371 ayat (2) BW terdapat pedoman yang isinya "Juga penggantian kerugian ini dinilai berdasarkan kedudukan dan kemampuan kedua belah pihak, dan menurut keadaan". ${ }^{16}$ Pedoman selanjutnya mengenai ganti kerugian dalam perbuatan melanggar hukum bisa dilihat dalam Pasal 1372 ayat (2) BW yang isinya: "Dalam menilai suatu dan lain, Hakim harus memperhatikan berat ringannya penghinaan, begitu pula pangkat, kedudukan dan kemampuan kedua belah pihak, dan pada keadaan". Unsur kerugian dalam penyalahgunaan data pribadi berupa nomor kontak pihak ketiga oleh penerima pinjaman dan penyelenggara pinjaman online dalam perjanjian pinjam

\footnotetext{
${ }^{14}$ Sri Redjeki Slamet, 'Tuntutan Ganti Rugi Dalam Perbuatan Melawan Hukum: Suatu Perbandingan Dengan Wanprestasi' (2013) 10 Lex Jurnalica (Journal of Law).[117].

${ }^{15}$ Hassanah, Op.Cit.[49].

${ }^{16}$ Bimo Prasetio and Rizky Dwinanto, 'Di Mana Pengaturan Kerugian Konsekuensial Dalam Hukum Indonesia? - Klinik Hukumonline' (Hukumonline, 4 July 2011) <https:/ / www.hukumonline. com/klinik/a/di-mana-pengaturan-kerugian-konsekuensial-dalam-hukum-indonesia-lt4da27259c45b9> accessed 13 February 2022.
} 
- meminjam uang secara online yaitu berupa kerugian materiil yang berupa kebocoran data pribadi milik pihak ketiga. Larangan mengenai penggunaan data pribadi dalam Pasal 26 UU ITE memiliki maksud bahwa data pribadi merupakan suatu aset yang memiliki nilai ekonomi sehingga apabila dimanfaatkan oleh orang lain yang tidak berhak, maka akan menimbulkan kerugian ekonomis terhadap pemiliknya ${ }^{17}$ Selain itu terdapat kerugian immateriil dimana penerima pinjaman dan penyelenggara pinjaman online tersebut dapat mengakses nomor pribadi pihak ketiga dan menyebarluaskan nomor pihak ketiga yang berakibat mengganggu ketentraman dan menyebabkan ketakutan pihak ketiga karena nomornya dapat diakses oleh penyelenggara pinjaman online.

d. Adanya hubungan sebab akibat antara perbuatan melanggar hukum,

\section{kesalahan dan kerugian yang ada}

Ajaran kausalitas dalam hukum perdata yaitu untuk meneliti adakah hubungan kausalitas atau sebab-akibat antara perbuatan melanggar hukum dan kerugian yang ditimbulkan, sehingga si pelaku dapat dipertanggungjawabkan atas kesalahannya. ${ }^{18}$ Hubungan kausalitas dapat ditinjau dari dua teori, yaitu teori Conditio Sine Qua Non, yaitu pelaku perbuatan melanggar hukum selalu bertanggung gugat dan teori Adequate Veroorzaking, yaitu pelaku yang melakukan perbuatan melanggar hukum hanya bertanggung gugat atas kerugian yang merupakan akibat dari perbuatannya tersebut yang seyogyanya dapat diperkirakan timbul. ${ }^{19}$ Dalam perjanjian pinjam meminjam uang secara online tersebut melakukan penyalahgunaan data pribadi berupa nomor pihak ketiga yang mengakibatkan kerugian terhadap pihak ketiga.Dalam hal penerima pinjaman memberikan akses nomor milik pihak ketiga kepada penyelenggara pinjaman online tanpa persetujuan secara tegas oleh pihak ketiga bersangkutan, maka penyelenggara pinjaman online dapat menggunakan atau mengakses nomor tersebut untuk digunakan sebagai akses darurat sekiranya penerima

${ }^{17}$ Muhamad Hasan Rumlus and Hanif Hartadi, ‘Kebijakan Penanggulangan Pencurian Data Pribadi Dalam Media Elektronik' (2020) 11 Jurnal HAM.[294].

${ }^{18}$ Slamet, Op.cit.[117].

${ }^{19}$ Putra and Anand, Op.cit.[114]. 
pinjaman tidak dapat dihubungi, bahkan dapat mengusik pihak ketiga yang tidak berkepentingan dalam perjanjian pinjam-meminjam untuk dapat melunasi utang penerima pinjaman. Dapat dilihat bahwa terdapat hubungan kausalitas dimana perbuatan yang dilakukan penerima pinjaman dan penyelenggara pinjaman online akibat kesalahannya secara langsung merugikan pihak ketiga selaku pemilik nomor yang bersangkutan.

Unsur-unsur di atas merupakan syarat materiil untuk mengajukan gugatan ganti rugi atas dasar perbuatan melanggar hukum. Dengan terpenuhinya unsurunsur di atas, maka pihak ketiga dapat mengajukan gugatan ganti rugi. Gugatan ganti rugi yang dapat diajukan dalam hal ini dapat berupa ganti rugi materiil atas kerugian kebocoran data yang dialami oleh pihak ketiga yang seharusnya hanya ia saja yang dapat memanfaatkan data pribadinya dan/atau dapat berupa ganti rugi immateriil yang didasari atas perasaan takutnya bahwa data pribadinya disalahgunakan oleh orang lain. Dimana hal tersebut mengganggu ketentraman pihak ketiga yang dhubungi oleh penyelenggara pinjaman online terus - menerus. Di sisi lain pihak ketiga tersebut tidak memiliki hubungan hukum dengan penerima pinjaman dan penyelenggara pinjaman online dalam perjanjian pinjam - meminjam uang secara online tersebut. Pihak ketiga tersebut hanyalah korban yang tidak tahu-menahu jika data pribadi berupa nomor kontaknya diguna kan penerima pinjamantanpa persetujuannya sebagai akses darurat jika penerima pinjaman gagal bayar kepada penyelenggara pinjaman online. Penerima pinjaman dianggap sengaja dikarenakan tidak menanyakan dahulu kepada pihak ketiga pada saat memberikan persetujuan kepada penyelenggara pinjaman online untuk memberikan akses daftar kontak yang dimilikinya, apakah pihak ketiga yang dicantumkan nomornya oleh penerima pinjaman setuju atau tidak nomor nya diakses oleh penyelenggara pinjaman online jika penerima pinjaman gagal bayar kepada penyelenggara pinjaman online.

Pada hukum pembuktian sebagaimana diatur dalam Pasal 1865 dan Pasal 1866 BW, yang menegaskan prinsip pembuktian bahwa setiap orang yang merasa memiliki hak atau merasa haknya terganggu, maka harus dapat membuktikannya 
secara hukum. Pembuktian yang dimaksud, harus mengikuti ketentuan alat bukti yang diakui secara hukum sebagaimana ditegaskan dalam Pasal 1866 Jo. Pasal 164 Het Herziene Indonesisch Reglement (selanjutnya disebut sebagai HIR), yang terdiri dari:

\section{Bukti surat/tertulis}

Mengenai hal ini diatur dalam Pasal 137, 138, 165, 167 HIR; Pasal 164, 285, 305 RBg. Menurut Sudikno Mertokusumo, alat bukti tertulis atau surat ialah segala sesuatu yang memuat tanda-tanda baca, dimaksudkan untuk mencurahkan isi hati atau menyampaikan buah pikiran seseorang dan dipergunakan sebagai pembuktian. Dengan demikian maka segala sesuatun yang tidak memuat tanda-tanda baca, atau meskipun memuat tanda-tanda baca akan tetapi tidak mengandung buah pikiran, tidaklah termasuk dalam pengertian alat bukti tertulis atau surat. Surat merupakan alat bukti utama untuk membuktikan adanya perbuatan hukum yang dikemudian hari timbul perselisihan bentuk surat tersebut yaitu berbentuk tulisan. Surat terbagi atas dua macam yaitu akta dan surat - surat lainnya yang bukan akta (surat biasa). Akta juga dibagi dalam 2 macam yaitu akta otentik dan akta dibawah tangan. Untuk dapat dijadikan sebagai akta maka surat tersebut harus ditandatangani sebagaimana dalam ketentuan Pasal 1869 BW. Akta otentik yaitu akta yang bentuknya ditentukan oleh undang-undang, dan dibuat oleh atau di hadapan pegawai-pegawai umum (pejabat umum) yang berkuasa untuk itu di tempat, sedangkan akta dibawah tangan adalah akta yang dibuat bukan dengan bantuan pejabat yang berwenang dan dibuat dengan tujuan untuk kepentingan para pihak. Mengenai penggolongan surat biasa yang bukan akta diatur secara khusus sebagaimana dalam Pasal 1881 BW dan Pasal 1883 BW yaitu buku daftar, surat - surat rumah tangga dan catatan - catatan yang diberikan oleh seorang penyelenggara pinjaman online yang memiliki suatu 
alas hak untuk dipegang selamanya; ${ }^{20}$

\section{Bukti saksi}

Alat bukti saksi yaitu orang yang memberikan kesaksiannya di dalam persidangan pengadilan. Kesaksian adalah kepastian yang diberikan kepada hakim di persidangan tentang peristiwa yang disengketakan dengan jalan pemberitahuan secara lisan dan pribadi oleh orang yang bukan salah satu pihak dalam perkara, yang dipanggil di persidangan. Dengan demikian, keterangan yang dikemukakan oleh saksi itu harus hal-hal tentang peristiwa atau kejadian yang dilihat atau dialami sendiri. Seseorang yang melihat atau mengalami sendiri kejadian itu memang ada dengan sengaja diajak untuk menyaksikannya, akan tetapi ada juga yang hanya secara kebetulan saja; ${ }^{21}$

\section{Bukti persangkaan}

Berdasarkan ketentuan pasal 1866 BW dan Pasal 164 H.I.R persangkaan merupakan alat bukti yang dicantumkan pada urutan ketiga setelah alat bukti surat dan alat bukti saksi. Persangkaan adalah kesimpulan yang tertarik dari suatu peristiwa yang telah terkenal atau dianggap terbukti kearah suatu peristiwa yang telah atau dianggap terbukti ke arah suatu peristiwa yang tidak terkenal artinya belum terbukti. Adapun yang menarik kesimpulan tersebut adalah hakim atau undang-undang. Sehingga dalam hal ini apabila yang menarik kesimpulan itu adalah hakim, maka persangkaan itu dinamakan "Persangkaan Hakim", sedangkan apabila yang menarik kesimpulan undangundang maka persangkaan itu dinamakan "Persangkaan undang-undang". Menurut Pasal 1922 BW persangkaan-persangkaan yang tidak berdasarkan undang-undang sendiri diserahkan kepada pertimbangan dan kewaspadaan hakim, namun tidak boleh memperhatikan persangkaan lain selain yang penting dan tertentu serta sesuai satu sama lainnya. Persangkaan-persangkaan

\footnotetext{
${ }^{20}$ Efa Laela Fakhriah, 'Perkembangan Alat Bukti Dalam Penyelesaian Perkara Perdata Di Pengadilan Menuju Pembaruan Hukum Acara Perdata' (2015) 1 Jurnal Hukum Acara Perdata Adhaper.[140].

${ }^{21}$ Hendri Jayadi Pandiangan, ‘Perbedaan Hukum Pembuktian Dalam Perspektif Hukum Acara Pidana Dan Perdata’ (2017) 3 To-Ra.[577].
} 
yang demikian hanyalah boleh dianggap dalam hal di mana undang-undang mengijinkan pembuktian dengan saksi-saksi, begitu pula apabila dimajukan suatu bantahan terhadap perbuatan atau suatu akta, berdasarkan alasan adanya itikad buruk atau penipuan. Demikian pula menurut pasal 173 H.I.R., persangkaan saja yang tidak berdasarkan suatu peraturan undang-undang yang tertentu, hanya hams diperhatikan oleh hakim waktu menjatuhkan putusan, jika persangkaan itu penting, seksama, tertentu dari satu sama lain bertujuan; ${ }^{22}$

\section{Bukti pengakuan}

Bukti pengakuan baik HIR maupun BW tidak menerangkan atau mengatur secara jelas. Bukti pengakuan dalam HIR diatur dalam Pasal 174 HIR, Pasal 175 HIR dan Pasal 176 HIR sedangkan dalam BW diatur pada Pasal 1923 BW sampai dengan Pasal 1928 BW. Pengakuan adalah keterangan sepihak dari salah satu pihak dalam satu perkara, di mana ia mengakui apa yang dikemukakan oleh pihak lawan atau sebahagian dari apa yang dikemukakan oleh pihak lawan. Apabila berpedoman pada ketentuan undang-undang maka mengenai pengakuan adalah jelas merupakan salah satu alat pembuktian, hal ini terbukti dengan memperhatikan ketentuan Pasal 164 HIR dan Pasal 1866 BW. Walaupun undang-undang menganggap pengakuan itu sebagai salah satu alat pembuktian, akan tetapi banyak para ahli hukum yang berpendapat sebaliknya; ${ }^{23}$

\section{Bukti sumpah}

Alat bukti sumpah pengaturannya terdapat dalam Pasal 155-158, 177 HIR. Alat bukti sumpah bisa dipergunakan untuk upaya terakhir dalam membuktikan terkait kebenaran dari prosessengketa perdata, dikarenakan sepanjang alat bukti lainnya masih bisa digunakan maka dalam hal ini sumpah lebih baik dikesampingkan penggunaannya. Sumpah secara umumyaitu

\footnotetext{
${ }^{22}$ Wawan Susilo, 'Penggunaan Alat Bukti Kesaksian "De Auditu” Dalam Membuktikan Kebenaran Sengketa Perdata' (2015) 3 IUS.[57].

${ }^{23}$ Pandiangan, Op.Cit.[580].
} 
bentuk pernyataan yang khidmat yang diucapkan pada saat memberikan janji atau keterangan dengan mengingat agama yaitu Tuhan Yang Maha Esa serta memberikan kepercayaan bahwa seseorang yang memberi keterangan atau janji yang tidak sebenar-benarnya akan dihukum oleh Tuhan Yang Maha Esa. ${ }^{24}$

Dalam kaitannya dengan penyalahgunaan data pribadi berupa nomor pihak ketiga dalam perjanjian pinjam - meminjam uang secara online tersebut maka pihak ketiga dapat membubuhkan alat bukti elektronik sebagaimana dalam Pasal 5 UU ITE yang menyebutkan bahwa:

1. Informasi Elektronik dan/atau Dokumen Elektronik dan/atau hasil cetaknya merupakan alat bukti hukum yang sah;

2. Informasi Elektronik dan/atau terkait hasil pencetakannya sebagaimana dalam ayat (1) yaitu sebuahketentuan luas dari alat bukti yang sah yang diatur dalam Hukum Acara di Indonesia.

Dengan demikian, maka persetujuan pemberian nomor pribadi pihak ketiga yang dilakukan oleh penerima pinjaman kepada penyelenggara pinjaman online tersebut untuk akses darurat menagih utang penerima pinjaman kepada penyelenggara pinjaman online dapat dijadikan bukti elektronik. Selain itu bukti lainnya dapat berupa riwayat telepon atau percakapan secara online melalui media sosial antara penyelenggara pinjaman online dengan pihak ketiga yang menagih utang penerima pinjaman kepada pihak ketiga. Hal ini juga sejalan dengan pengaturan UNCITRAL Model Law on Electronic Commerce yang menetapkan beberapa prinsip hukum, yaitu: ${ }^{25}$

a. Semua informasi elektronik berbentuk alat bukti data elektronik bisa disebut sebagai alat bukti yang mempunyai akibat hukum, keabsahan serta kekuatan hukum;

b. Dalam hal hukum mengharuskan adanya sesuatu informasi maka harus dalam bentuk tertulis, harus dianggap memenuhi syarat untuk itu;

c. Dalam hal tanda tangan maka sesuatu tanda tangan elektronik merupakan

\footnotetext{
${ }^{24}$ Enju Juanda, 'Kekuatan Alat Bukti Dalam Perkara Perdata Menurut Hukum Positif Indonesia' (2016) 4 Jurnal Ilmiah Galuh Justisi.[42].

25 Efa Laela Fakhriah, ‘Penemuan Hukum Oleh Hakim Melalui Pembuktian Dengan Menggunakan Bukti Elektronik Dalam Mengadili Dan Memutus Sengketa Perdata' (2020) 5 Jurnal Bina Mulia Hukum.[97].
} 
tangan tangan yang sah;

d. Dalam hal ketentuan pembuktian dari data yang bersangkutan dari data message memiliki kekuatan pembuktian.

Kekuatan pembuktian dokumen elektronik yang disetarakan dengan dokumen yang dibuat di atas kertas, menurut penjelasan umum UU ITE dipandang perlu untuk memahami kekuatan pembuktian alat bukti tertulis (surat) sebagaimana yang tercantum dalam BW. Kekuatan pembuktian dokumen elektronik yang secara tegas diakui, dan disetarakan dengan dokumen yang dibuat di atas kertas, sangat memungkinkan untuk dilakukan, mengingat sifat dokumen elektronik yang dapat dialihkan kedalam beberapa bentuk atau dicetak dalam bentuk print out sehingga, dipersamakan dengan dokumen yang dibuat di atas kertas. ${ }^{26}$

Dengan demikian, semua alat bukti tersebut dapat menjadi alat bukti dalam proses pembuktian perkara perdata termasuk yang berhubungan dengan kontrak atau perjanjian. Berdasarkan ketentuan Pasal 1865 BW, pihak yang merasa memiliki hak atau merasa haknya secara perdata terganggu, maka harus dapat membuktikannya, Dengan cara dan metode pembuktian yang telah ditentukan dalam hukum acara perdata. Namun demikian tidak berarti pihak lainnya tidak memiliki hak untuk melakukan pembuktian pula, artinya masing-masing pihak memiliki hak yang sama dalam proses pembuktian. Urutan alat bukti yang dapat diajukan adalah sebagaimana telah disebutkan dalam Pasal 1866 BW Jo. Pasal 164 HIR di atas, secara mutatis mutandis. Ada beberapa prinsip pembuktianyang harus diperhatikan antara lain: ${ }^{27}$

a. Asas pembuktian dilakukan secara seimbang antara para pihak yang bersengketa;

b. Asas testimonium de auditu artinya bahwa bukti saksi dalam proses pembuktian adalah segala sesuatu yang dilihat, didengar dan dialami sendiri oleh saksi

${ }^{26}$ Anisah Daeng Tinring, Dachran Bustahmi and Ahyuni Yunus, 'Kedudukan Dokumen Elektronik Sebagai Alat Bukti Dalam Hukum Acara Perdata Di Indonesia' (2019) 1 Celebes Cyber Crime.[57].

${ }^{27}$ Hassanah, Op.Cit.[47]. 
dan bukan keterangan orang lain;

c. Asas satu saksi bukan saksi, artinya bahwa alat bukti saksi harus didukung dengan alat bukti saksi lainnya sesuai peraturan perundangan yang berlaku dalam hukum acara perdata.

Pasal 1365 BW dapat dijadikan sebagai dasar hukum tuntutan ganti kerugian atas perbuatan melanggar hukum terhadap penyalahgunaan data pribadi elektronik dengan dukungan pembuktian berdasarkan data elektronik yang diakui sebagai bukti yang sah seperti dalam hukum acara yang berlaku di Indonesia, telah diatur dalam Pasal 5 UU ITE. Oleh karena itu, BW dan UU ITE sangat berperan dalam menghadapi kendala terkait tuntutan ganti kerugian atas perbuatan melanggar hukum dalam transaksi tersebut. ${ }^{28}$ Bukti elektronik yang dimaksud dapat berupa bukti riwayat panggilan dan riyawat percakapan melalui media sosial. Selain itu, upaya hukum yang diajukan adalah gugatan atas dasar perbuatan melanggar hukum bukan wanprestasi, maka harus dibuktikan mengenai perbuatan melanggar hukum tersebut dan hubungannya dengan kerugian yang terjadi. Tidak seperti gugatan terhadap wanprestasi yang dapat dibuktikan dengan tidak dipenuhinya atau dilanggarnya ketentuan dalam perjanjian yang dibuatnya. Dengan demikian, pembuktian terbalik merupakan solusi yang tepat untuk membuktikan bahwa penerima pinjaman dan penyelenggara pinjaman online benar-benar bersalah atau tidak dalam penyalahgunaan data pribadi yang diserahkan oleh pemiliknya. Tentu hal ini tidak mudah untuk dilakukan, mengingat kurangnya peraturan mengenai perlindungan data pribadi dan solusi yang diberikan atas penyalahgunaan tersebut. UU ITE tidak mengatur secara rinci mengenai gugatan ganti rugi yang diajukan dalam hal terjadi penyalahgunaan data pribadi berupa nomor pihak ketiga oleh penyelenggara pinjaman online dalam perjanjian ini oleh pihak, namun meskipun demikian pihak ketiga yang merasa dirugikan akibat penyalahgunaan datanya tetap memiliki hak untuk mengajukan gugatan kepada Pengadilan karena telah dilanggarnya hak pribadinya.

${ }^{28}$ ibid. [50]. 


\section{Kesimpulan}

Penyalahgunaan data pribadi berupa nomor pribadi pihak ketiga yang dilakukan oleh debitur perjanjian pinjam - meminjam uang secara online merupakan perbuatan melanggar hukum yang melanggar hak subjektif pihak ketiga yang bersangkutan karena melakukan pengaksesan nomor yang dilakukan tanpa persetujuan dari pihak ketiga yang bersangkutan sebagaimana telah diatur pula dalam Pasal 26 UU ITE. Berdasarkan Pasal 1365 BW, terhadap perbuatan melanggar hukum tersebut dapat diajukan gugatan ganti rugi dengan syarat harus memenuhi unsur-unsur berupa adanya perbuatan melanggar hukum, adanya kesalahan, adanya kerugian dan adanya hubungan sebab akibat antara perbuatan melanggar hukum, kesalahan dan kerugian tersebut. Dengan demikian, pihak ketiga yang merasa dirugikan karena perbuatan penyalahgunaan yang dilakukan oleh penerima pinjaman dan penyelenggara pinjaman online perjanjian pinjammeminjam uang secara online dapat mengajukan gugatan ganti rugi baik materiil maupun imateriil. Berkenaan dengan hal tersebut, disarankan beberapa hal:

a. Penerima pinjaman wajib menerapkan prinsip kehati-hatian sebelum membuat perjanjian pinjam-meminjam uang melalui aplikasi pinjaman online.

b. Pemerintah dapat menjelaskan secara mendetail dalam peraturan perundangundangan terkait jenis data pribadi yang wajib dilindungi.

c. Pemerintah perlu membuat peraturan pelaksana yang lebih rinci terkait upaya terhadap perbuatan penyalahgunaan data pribadi khususnya dalam pengaksesan nomor kontak pribadi.

\section{Daftar Bacaan}

\section{Buku}

Hernoko AY, Hukum Perjanjian: Asas Proporsionalitas Dalam Kontrak Komersial (Prenadamedia Group 2014).

Marzuki PM, Penelitian Hukum: Edisi Revisi (Prenada Media 2017).

Subekti, Pokok-Pokok Hukum Perdata (Intermasa 2003). 
Suharnoko, Hukum Perjanjian (Prenada Media 2004).

\section{Jurnal}

Fakhriah EL, 'Perkembangan Alat Bukti Dalam Penyelesaian Perkara Perdata Di Pengadilan Menuju Pembaruan Hukum Acara Perdata' (2015) 1 Jurnal Hukum Acara Perdata Adhaper 135.

Hassanah H, 'Analisis Hukum Tentang Perbuatan Melawan Hukum Dalam Transaksi Bisnis Secara Online (E-Commerce) Berdasarkan Burgerlijke Wetboek Dan Undang-Undang Nomor 11 Tahun 2008 Tentang Informasi Dan Transaksi Elektronik' (2016) 32 Jurnal Wawasan Yuridika 38.

Juanda E, 'Kekuatan Alat Bukti Dalam Perkara Perdata Menurut Hukum Positif Indonesia' (2016) 4 Jurnal Ilmiah Galuh Justisi 27.

Laela Fakhriah E, 'Penemuan Hukum Oleh Hakim Melalui Pembuktian Dengan Menggunakan Bukti Elektronik Dalam Mengadili Dan Memutus Sengketa Perdata' (2020) 5 Jurnal Bina Mulia Hukum 89.

Pandiangan HJ, 'Perbedaan Hukum Pembuktian Dalam Perspektif Hukum Acara Pidana Dan Perdata' (2017) 3 To-Ra 565.

Putra F and Anand G, 'Perlindungan Hukum Terhadap Para Pihak Yang Dirugikan Atas Penyuluhan Hukum Oleh Notaris' (2018) 8 Hukum dan Masyarakat Madani 105.

Rizqy R and Syahrizal S, 'Tinjauan Yuridis Terhadap Perbuatan Melawan Hukum Dan Sanksi Nya' (2019) 3 Jurnal Justisia : Jurnal Ilmu Hukum, Perundangundangan dan Pranata Sosial 239.

Rosadi SD, 'Prinsip-Prinsip Perlindungan Data Pribadi Nasabah Kartu Kredit Menurut Ketentuan Nasional Dan Implementasinya' (2017) 19 Sosiohumaniora 206.

Rumlus MH and Hartadi H, 'Kebijakan Penanggulangan Pencurian Data Pribadi Dalam Media Elektronik' (2020) 11 Jurnal HAM 285.

Sari I, 'Perbuatan Melawan Hukum (PMH) Dalam Hukum Pidana Dan Hukum Perdata' (2020) 11 Jurnal Ilmiah Hukum Dirgantara 53.

Slamet SR, 'Tuntutan Ganti Rugi Dalam Perbuatan Melawan Hukum: Suatu Perbandingan Dengan Wanprestasi' (2013) 10 Lex Jurnalica (Journal of Law) 107. 
Susilo W, 'Penggunaan Alat Bukti Kesaksian “De Auditu” Dalam Membuktikan Kebenaran Sengketa Perdata' (2015) 3 IUS 51.

Tinring AD, Bustahmi D and Yunus A, 'Kedudukan Dokumen Elektronik Sebagai Alat Bukti Dalam Hukum Acara Perdata Di Indonesia' (2019) 1 Celebes Cyber Crime 27.

Yuniarlin P, 'Penerapan Unsur-Unsur Perbuatan Melawan Hukum Terhadap Penyelenggara Pinjaman Online Yang Tidak Mendaftarkan Jaminan Fiducia' (2012) 19 Jurnal Media Hukum.

\section{Laman}

Prasetio B and Dwinanto R, ‘Di Mana Pengaturan Kerugian Konsekuensial Dalam Hukum Indonesia? - Klinik Hukumonline' (Hukumonline, 4 July 2011) <https://www.hukumonline.com/klinik/a/di-mana-pengaturankerugian-konsekuensial-dalam-hukum-indonesia--lt4da27259c45b9> accessed 13 February 2022.

Sugali, 'Gugatan Perdata Perbuatan Melawan Hukum' (Sugali \& Rekan, 20 May 2020) <https://sugalilawyer.com/gugatan-perdata-perbuatan-melawanhukum/> accessed 13 February 2022.

\section{Perundang-undangan}

Burgerlijk Wetboek voor Indonesie (Staatsblaad Nomor 23 Tahun 1847).

Undang-Undang Nomor 10 Tahun 1994 tentang Perubahan Atas Undang-Undang Nomor 7 Tahun 1983 Tentang Pajak Penghasilan Sebagaimana Telah Diubah Dengan Undang-Undangnomor 7 Tahun 1991 (Lembaran Negara Republik Indonesia Tahun 1994 Nomor 60, Tambahan Lembaran Negara Republik Indonesia Nomor 3567).

Undang-Undang Nomor 37 Tahun 2004 tentang Kepailitan dan Penundaan Kewajiban Pembayaran Utang (Lembaran Negara Republik Indonesia Tahun 2004 Nomor 131, Tambahan Lembaran Negara Republik indonesia Nomor 4443).

Peraturan Presiden Republik Indonesia Nomor 9 Tahun 2009 tentang Lembaga Pembiayaan.

Keputusan Menteri Perdagangan Dan Koperasi Republik Indonesia Nomor 34/ KP/II/80 Tahun 1980 tentang Perizinan Kegiatan Usaha Sewa Guna Usaha (Hire Purchase) Jual Beli Dengan Angsuran, dan Sewa (Renting) dicabut oleh Peraturan Menteri Perdagangan Republik Indonesia Nomor 21/M-Dag/ 
130 Indira Retno, dkk: Tanggung Gugat Penerima...

PER/10/2005 Tahun 2005 tentang Pencabutan Beberapa Perizinan Dan Pendaftaran di Bidang Perdagangan.

Keputusan Menteri Keuangan Republik Indonesia Nomor 1169/KMK.01/1991 Tentang Kegiatan Sewa Guna Usaha (Leasing).

Putusan Nomor 355 K/Pdt.Sus-Pailit/2020.

How to cite: Indira Retno Aryatie, Farah Diba, Karina Ardelia Irnanda, ‘Tanggung Gugat Penerima Pinjaman Aplikasi Pinjaman Online atas Penyalahgunaan Data Pribadi Milik Pihak Ketiga' (2022) Vol. 5 No. 1 Notaire. 